\title{
Dilation lag in Horner syndrome can be measured with a diagnostic imaging system
}

Francesco Pellegrini, MD, Gianluca Capello, MD, and Romeo Napoleone, MD

Correspondence

Neurology ${ }^{\circledR}$ 2018;90:618. doi:10.1212/WNL.0000000000005217

Dr. Pellegrini

francepellegrini@virgilio.it

Figure Frames caught by a 10-second video and pupils calculated through a caliper

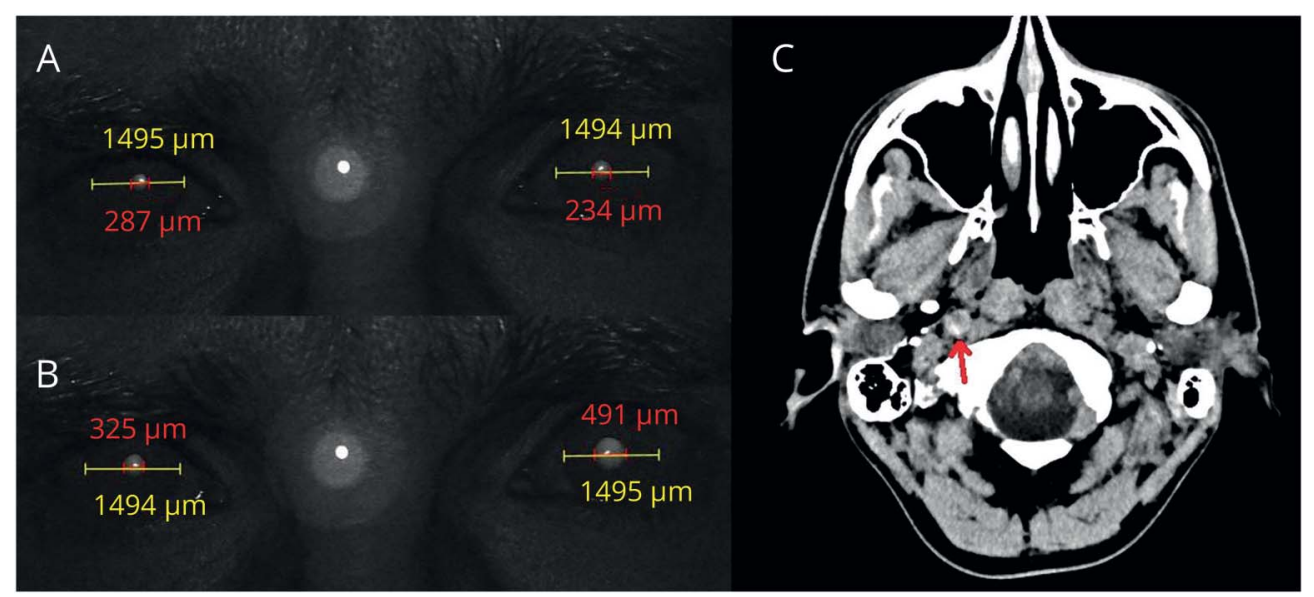

In standard room light condition, the pupil diameters are almost the same (A), while a right dilation lag can be measured after turning the light off (B). Contrast brain CT scan shows internal carotid artery dissection (C, arrow).

A 45-year-old man presented to the emergency department complaining of retrobulbar discomfort. A neuro-ophthalmology consultation showed ptosis of the right upper eyelid. Both pupils were briskly reactive to light with no right afferent pupillary defect. A dilation lag was sought with a Spectralis machine (Heidelberg Engineering, Heidelberg, Germany). While the diameter of the pupils was almost the same (figure, A), in regular room light a dilation lag of the right pupil was detected when the light was turned off (figure, B). An urgent contrast brain CT scan confirmed a right internal carotid artery dissection (figure, C).

\section{Author contributions}

Francesco Pellegrini: critical revision of the manuscript. Gianluca Capello: patient selection. Romeo Napoleone: study concept and design.

\section{Study funding}

No targeted funding reported.

\section{Disclosure}

The authors report no disclosures relevant to the manuscript. Go to Neurology.org/N for full disclosures. 


\section{Neurology}

Dilation lag in Horner syndrome can be measured with a diagnostic imaging system Francesco Pellegrini, Gianluca Capello and Romeo Napoleone Neurology 2018;90;618

DOI 10.1212/WNL.0000000000005217

This information is current as of March 26, 2018

$\begin{array}{ll}\begin{array}{l}\text { Updated Information \& } \\ \text { Services }\end{array} & \begin{array}{l}\text { including high resolution figures, can be found at: } \\ \text { http://n.neurology.org/content/90/13/618.full }\end{array} \\ \text { Subspecialty Collections } & \begin{array}{l}\text { This article, along with others on similar topics, appears in the } \\ \text { following collection(s): } \\ \text { Carotid artery dissection } \\ \text { http://n.neurology.org/cgi/collection/carotid_artery_dissection }\end{array} \\ \text { Permissions \& Licensing } & \begin{array}{l}\text { Information about reproducing this article in parts (figures,tables) or in } \\ \text { its entirety can be found online at: } \\ \text { http://www.neurology.org/about/about_the_journal\#permissions }\end{array} \\ & \begin{array}{l}\text { Information about ordering reprints can be found online: } \\ \text { http://n.neurology.org/subscribers/advertise }\end{array}\end{array}$

Neurology ${ }^{\circledR}$ is the official journal of the American Academy of Neurology. Published continuously since 1951, it is now a weekly with 48 issues per year. Copyright () 2018 American Academy of Neurology. All rights reserved. Print ISSN: 0028-3878. Online ISSN: 1526-632X.

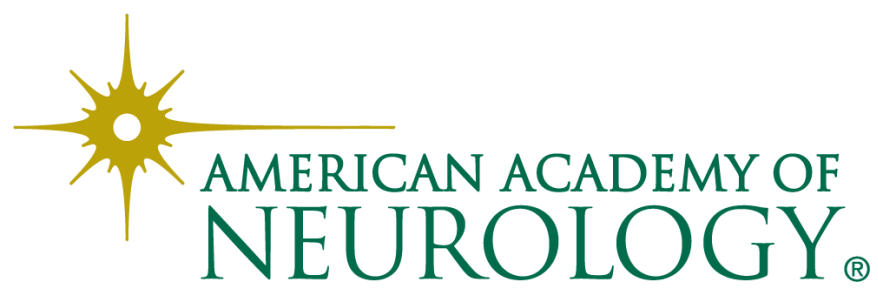

